\title{
Article \\ Sustainable Silage Maize Integrated Protection against the European Corn Borer Ostrinia nubilalis and the Corn Earworm Helicoverpa armigera Employing the Farm Irrigation System
}

\author{
Luca Ruiu * (D) and Andrea Lentini (D) \\ Dipartimento di Agraria, University of Sassari, Viale Italia 39/A, 07100 Sassari, Italy; lentini@uniss.it \\ * Correspondence: lucaruiu@uniss.it
}

\begin{abstract}
Silage corn is an important source of feed in animal husbandry, often affected by the feeding action of diverse corn borers that can compromise harvest quality and quantity. According to the need to reduce the use of chemical insecticides, the main purpose of this study was to evaluate the efficacy of different IPM programs comparing microbial (Btk and baculovirus) and chemical control methods, alone or combined, against $O$. nubilalis and $H$. armigera. Assessments were based on counting the number of larvae, inspecting plants superficially and inside the stem, and estimating the derived damages. All tested products proved to be effective in containing the density of these lepidopteran species, with microbial control agents having comparable efficacy in respect to the reference chemical substances (lambda-cialotrina and chlorantraniliprole), even if periodic treatment repetition was required to ensure over-time protection until harvest. Both Btk and HaNPV were successfully applied by the irrigation system during flowering and fruit development periods, when plant height did not allow the use of a tractor-mounted spray bar. This biocontainment approach appears to be sustainable and technically compatible with farm needs.
\end{abstract}

Citation: Ruiu, L.; Lentini, A.

Sustainable Silage Maize Integrated Protection against the European Corn Borer Ostrinia nubilalis and the Corn Earworm Helicoverpa armigera Employing the Farm Irrigation System. Agronomy 2022, 12, 362. https://doi.org/10.3390/ agronomy12020362

Keywords: Bacillus thuringiensis; baculovirus; microbial control; IPM; bioinsecticides

Academic Editor: Ivo Toševski

Received: 30 December 2021

Accepted: 29 January 2022

Published: 31 January 2022

Publisher's Note: MDPI stays neutral with regard to jurisdictional claims in published maps and institutional affiliations.

Copyright: (C) 2022 by the authors. Licensee MDPI, Basel, Switzerland. This article is an open access article distributed under the terms and conditions of the Creative Commons Attribution (CC BY) license (https:// creativecommons.org/licenses/by/ $4.0 /)$.

\section{Introduction}

Silage corn represents a fundamental resource for livestock farmers in different areas of the world, being a strategic crop and a source of feed in animal husbandry [1]. Cultivation of this crop in a sustainable way requires particular attention to the choice of varieties and inputs to the agroecosystem, such as fertilization, irrigation, and defense against weeds, pests, and pathogens [2]. Among insect pests, a prominent role is played by diverse lepidoptera such as the European corn borer (ECB) Ostrinia nubilalis (Hübner) (Lepidoptera: Crambidae). This species has a variable number of generations (1-4) depending on the climatic conditions, but adult flights and oviposition normally occur in spring and summer, in southern regions, and therefore throughout the entire maize cultivation cycle [3]. As a result, the trophic activity of the young larvae causes damages to different plant tissues, including leaves, stalk, kernels, and cobs. Larvae often tunnel into the cob and the stalk, being able to cause a weakening of the plant and possible lodging [4]. The wounds on the plant caused by boring activity then may constitute a route of entry for fungal phytopathogens [5]. In addition to ECB, other lepidopteran pests that are frequently found on maize are several noctuid species, including the corn earworm Helicoverpa armigera (Hübner), and different Sesamia species [6]. In some Mediterranean areas, including the one involved in this study, certain species of significant worldwide importance, such as Spodoptera frugiperda (Lepidoptera: Noctuidae) Smith, are not yet present [7].

The management of ECB and other lepidopteran pests is a major issue in silage corn cultivation, and, according to integrated pest management (IPM) principles, the strategy of their population containment may include the use of less susceptible varieties, specific cultural practices (e.g., destruction of stalks where larvae overwinter), classical 
biological control (e.g., the launch of hymenopteran parasitoids such as Trichogramma spp.), pheromone-based mating disruption, and, finally, chemical treatments with liquid or granular formulations against young larvae [8]. A pest management issue is represented by the need to limit the overall use of chemicals in the agroecosystem and to reduce the risks of exceeding the related maximum residue levels (MRLs) in maize food and feed, which favors the employment of some botanicals and biological control agents, including microbial entomopathogens. The latter may include diverse species of fungi, viruses, and bacteria. Among entomopathogens, good efficacy can be obtained with strains of the spore-forming bacterium Bacillus thuringiensis subsp. kurstaki (Btk), targeting young lepidopteran larvae [9]. The bioinsecticidal action relies on insecticidal proteins (Cry), normally contained in parasporal crystals produced by the bacterium, which are part of its commercial formulations. Once ingested and dissolved in the insect midgut, protoxins are released from crystals and, after activation, interact with epithelial cell receptors through a very specific mode of action, leading to cell membrane permeability alteration and the consequent flux of ions and water, causing cell damage and disruption, followed by insect paralysis and death in a few days or hours depending on the ingested dose [10]. This efficacy justifies the development of resistant varieties of corn engineered with genes encoding for Cry proteins [11]. However, the cultivation of genetically modified organisms (GMOs) is not permitted in several regions of the world, including Europe [12]. Among entomopathogens, good efficacy is also expected with the use of baculoviruses, which represent natural and highly selective bioinsecticides specifically acting against their host [13]. The bioinsecticidal action of baculoviruses relates to the ingestion of crystalline occlusion bodies that contain infectious particles interacting directly with midgut epithelial cell membranes through specific envelope proteins (PIFs). Once infected, the virus replicates in the host tissues and produces a second type of virion (budded viruses), functional for the diffusion of the virus in the insect body. Then, dead insects liquefy, dispersing new viral particles in the environment, thus favoring the spread of the infection [14,15].

Insecticidal applications can be challenging in the advanced stages of cultivation, since maize plants grow very tall, reaching $3 \mathrm{~m}$, thus making distribution difficult with the tractormounted sprayers available in the farm. On the other hand, the possible use of vehicles with stilts over the rows, even when available, may encounter other limitations, such as poor soil sealing due to the intense wetting to which soil is subjected during frequent irrigation. A solution can be represented by the use of irrigation systems, which corn farms are normally equipped with. This method exploits the existing water distribution infrastructure to deliver agrochemicals, such as fertilizers and pesticides, helping farmers to reduce application costs. However, this system has to be properly designed to include adequate pumps for product injection and distribution at the correct rate and safety accessories to avoid any kind of water source contamination [16].

Although programs for the containment of these polyphagous lepidopteran pest species have been developed over time, their presence in mixed populations and the need to abandon or drastically reduce the use of chemical insecticides require the development of effective, yet environmentally friendly, strategies. The main purpose of this study was to evaluate the effectiveness of bioinsecticidal products applied by the irrigation system. The study involved several field trials and engaged different IPM programs, comparing microbial ( $B t$ and baculovirus) and chemical control methods, alone or combined, against major corn borer species (O. nubilalis and H. armigera).

\section{Materials and Methods}

\subsection{Insecticidal Products}

Larvicidal products employed in this study were commercially available and included two Btk-based formulations, BioBit DF (Sumitomo Chemical Italia Srl, Milan, Italy) and Costar WG (Certis Europe B.V., Saronno, VA, Italy), containing strains ABTS-351 and SA-12, respectively; a formulation based on Helicoverpa armigera baculovirus, Helicovex (Biogard, CBC Europe Srl, Grassobbio, BG, Italy); and two chemical reference products, Ampligo 
(Syngenta Italia Spa, Milan, Italy) and Coragen (Cheminova Agro Italia Srl, Bergamo, Italy). Characteristics of these products are reported in Table 1.

Table 1. Insecticidal products and active substances used in this study.

\begin{tabular}{|c|c|c|c|c|}
\hline Insecticide & $\begin{array}{l}\text { Active Ingredient } \\
\text { (Conc.) }\end{array}$ & Formulation & Manufacturer & Application Dose/ha \\
\hline BioBit DF & $\begin{array}{l}\text { Btk strain ABTS-351 } \\
(54 \% w / w)\end{array}$ & $\mathrm{DF}$ & $\begin{array}{c}\text { Sumitomo Chemical } \\
\text { Italia Srl }\end{array}$ & $1 \mathrm{~kg}$ \\
\hline Costar WG & $\begin{array}{c}\text { Btk strain SA-12 } \\
(18 \% w / w)\end{array}$ & WG & Certis Europe B.V. & $1 \mathrm{~kg}$ \\
\hline Helicovex & $\begin{array}{c}\text { Helicoverpa armigera } \\
\text { NucleoPoliedroVirus } \\
\text { (HaNPV) strain DSMZ } \\
\text { BV-0003 (min } 7.5 \times \\
\left.10^{12} \mathrm{~g} / \mathrm{L}\right)\end{array}$ & SC & $\begin{array}{c}\text { Biogard, CBC Europe } \\
\text { Srl }\end{array}$ & $0.2 \mathrm{~L}$ \\
\hline Ampligo & $\begin{array}{c}\text { lambda-cialotrina } g \\
4.63 \%(50 \mathrm{~g} / \mathrm{L}) \\
\text { chlorantraniliprole g } \\
9.26 \%(100 \mathrm{~g} / \mathrm{L})\end{array}$ & SC & Syngenta Italia Spa & $0.3 \mathrm{~L}$ \\
\hline Coragen & $\begin{array}{c}\text { Chlorantraniliprole g } \\
18.4(=200 \mathrm{~g} / \mathrm{L})\end{array}$ & SC & $\begin{array}{c}\text { Cheminova Agro Italia } \\
\text { Srl }\end{array}$ & $0.15 \mathrm{~L}$ \\
\hline
\end{tabular}

$\mathrm{DF}=$ Dry Flowable; $\mathrm{SC}=$ suspension concentrate; $\mathrm{WG}=$ water-dispersible granule.

\subsection{Experimental Site, Conditions, and Irrigation System}

This study was carried out in 2019 in Arborea (Sardinia, Italy), an agro-livestock area with an average maize cultivation surface of approximately 4000 ha, fragmented across different farms.

All experimental fields were sown in May with the corn hybrid MAS $78 \mathrm{~T}$ (Mas Seeds, Haut-Mauco France). Each field had an average size of 3 ha, where the experimental plots were identified.

Several trials were run to compare diverse active substances and formulations during the season. No other insecticides or fungicides were applied in the experimental fields during this period. All cultural conditions (i.e., soil type, fertilization, tillage) were uniform for all plots. Plants had an inter- and intra-row spacing of $75-80 \mathrm{~cm}$ and $20-25 \mathrm{~cm}$, respectively.

Main meteorological data (precipitation and temperature) were obtained from a nearby meteorological station (Figure S1). The irrigation system received water from the network of the local agricultural consortium, and its pipelines ran lengthwise across the field and were connected to vertical metal tubes, with a rotary sprayer at the upper end (10 m radius) allowing the crop to be evenly watered. Volume and timing regulation were centralized and controlled remotely. This system was used for insecticidal application in our experiments in the late stages of cultivation, when the plants were too tall to allow application with a tractor-mounted spray bar. For this purpose, single lines of the irrigation system were used as a tool for the application of bioinsecticides (Btk and HaNPV). This system was equipped with an injecting pump connected to a power take-off, which pushed the volume to be applied from a hopper towards a tube that was inserted into the head of the plot (Figure S2). In this way, a known amount of diluted product was distributed over the plot. For preliminary calibration, a simulation of insecticidal application was carried out with water treated with a blue dye. This water was injected into single irrigation lines and the time elapsed between injection at the head of the plot and the start and end of sprinkler delivery was measured visually. In this way, the time in which the system had to be in operation and its settings, to distribute the expected dose of product (Table 1) and the volume recommended on the label (1000 1/ha), were pre-determined. After application, irrigation was suspended for one week to avoid washout effects. A possibility that was not considered in this study was the use of specific additives to increase the product's adhesion to the plant, thus reducing the risks of being washed out by successive irrigation. 
Pheromone traps were routinely used to monitor the presence of O. nubilalis (Coretrap, Riff98, Bologna, Italy) and H. armigera (Traptest, Isagro Spa, Milan, Italy) in the experimental area during the trial period.

\subsection{Experiment 1}

This preliminary experiment had the purpose of comparing the efficacy of different products against a mixed larval population of $O$. nubilalis and $H$. armigera, with a prevalence of the latter, during the stem elongation growth stage, when larvae still had significant exophytic behavior, feeding on the leaves. The following products were applied on 24 June 2019 , by a tractor-mounted sprayer bar at BBCH growth stage 35, at the dose reported in Table 1 and a volume of 1000 1/ha: Btk (Costar), HaNPV (Helicovex), lambda-cialotrina + chlorantraniliprole (Ampligo), and chlorantraniliprole (Coragen). The trial had a completely randomized block design, in which each treatment had four replicates, and each replicate was represented by a $660 \mathrm{~m}^{2}$ plot (11 $\mathrm{m}$ wide and $60 \mathrm{~m}$ long), including 14 rows of maize plants. Assessments were based on counting the number of damaged plants, and the number of larvae detected in each plant, distinguishing between the two lepidopteran species, within a 100-plant sample randomly observed along a transect in each plot. Assessments were conducted just before the insecticidal application and every 7 days during the following 3 weeks.

\subsection{Experiment 2}

This experiment had the purpose of assessing the efficacy of Btk and HaNPV applied by the irrigation system on a mixed larval population almost entirely represented by $H$. armigera, during the flowering and fruit development period, when plants had an average height of more than $2.5 \mathrm{~m}$.

The experimental area included three homogeneous fields of around 3 ha each, bordered by eucalyptus fences. Each field was divided into three plots, each of 1 ha (33 m wide and $300 \mathrm{~m}$ long), to include two treatments (Costar and Helicovex) and the untreated control. Each product was applied twice (22/07 and 30/07) at the dose shown in Table 1 by the irrigation system as described above.

Given that both Btk and baculovirus act by ingestion, and applications from above allowed only superficial wetting, assessments targeted larvae detectable on the plant stem, leaves, including leaf axils, and the cob. The number of larvae per plant was assessed the day before the first application, and 7 and 21 days after the second application. For this purpose, 20 plants/plot, 5 taken consecutively on 4 rows, were randomly sampled and inspected for larval presence, according to the EPPO assessment protocol [17].

\subsection{Experiment 3}

This experiment had the purpose of comparing different pest management approaches in a farm mainly infested by $O$. nubilalis, wherein the irrigation system was the sole means available to the farmer for insecticidal applications during the advanced stages of cultivation. In this condition, no chemical products were allowed, but biological products were allowed to be used by the irrigation system.

The two pest management approaches are summarized in Table 2. All products were applied at the same dose reported in Table 1, when hatching larvae were detected on the plants. The trial involved three homogeneous fields of around 3 ha each, bordered by eucalyptus fences, wherein each field was divided into three plots of 1 ha (33 m wide and $300 \mathrm{~m}$ long), representing the three treatments (chemical, integrated, and untreated). 
Table 2. Insecticidal products applied in experiment 3 for each thesis (treatment).

\begin{tabular}{cccc}
\hline \multirow{2}{*}{ Treatment } & \multicolumn{3}{c}{ Plant Growth Stage at Application } \\
\cline { 2 - 4 } & $\begin{array}{c}\text { Stem Elongation } \\
(\mathbf{B B C H}=\mathbf{3 5 )}\end{array}$ & $\begin{array}{c}\text { Flowering } \\
\mathbf{( B B C H}=\mathbf{6 3 )}\end{array}$ & $\begin{array}{c}\text { End of Flowering } \\
\mathbf{( B B C H}=\mathbf{6 9 )}\end{array}$ \\
\hline Application date & 17 June & 23 July & 30 July \\
\hline Chemical & Ampligo & - & - \\
Integrated & Ampligo & BioBit & BioBit \\
Untreated & - & - & - \\
\hline
\end{tabular}

Assessments were conducted weekly from mid-June to the end of August, counting the number of plants with larval infestation and damage observable from the outside, along a transect of 100 plants per plot. In addition, more in-depth assessments were conducted at the stage of milky ripeness (6 August; $\mathrm{BBCH}=73$ ) and before harvest (21 August; $\mathrm{BBCH}=87)$, sampling 20 plants/plot, 5 taken consecutively on 4 rows, and counting the number of larvae on damaged plants and the number of penetrating holes. For this purpose, sampled plants were cut immediately above soil level and the stems split open along their length [17].

\subsection{Statistical Analysis}

Overtime differences in the percentage of infested plants and in the number of larvae or holes per plant were analyzed using repeated-measures ANOVA (PROC MIXED), and means were separated by LSMEANS comparison (adjust $=$ Tukey), using R software with significance level set at $\alpha=0.05$ [18]. Analysis of variance (ANOVA) followed by least significant difference (LSD) test $(p<0.05)$ was used to compare efficacy data on a specific date among treatments.

\section{Results}

\subsection{Experiment 1}

A homogeneous total larval infestation and consequent percentage of damage on plants was observed before insecticidal applications $\left(\mathrm{F}_{4,19}=0.68 ; p=0.61\right)$. Helicoverpa armigera was the dominant species in the experimental field during the trial period, but $O$. nubilalis larvae were sporadically observed. A significant total damage reduction $\left(\mathrm{F}_{4,79}=47.16 ; p<0.001\right)$ was found, as a result of diverse insecticidal applications in the experimental plots, in comparison with the untreated control (Figure 1). Larval density was also affected by time $\left(\mathrm{F}_{3,79}=29.52 ; p<0.001\right)$ and significant natural growth in plant damage percentages was observed in the untreated plots during the following three weeks, while the damage was limited in all treated plots. The density of $H$. armigera larvae on plants corroborated this trend, confirming the significant efficacy of all active substances tested against this pest $\left(\mathrm{F}_{4,79}=63.15 ; p<0.001\right)$, with a remarkable containment effect of Helicovex, based on the species-specific baculovirus $\mathrm{HaNPV}$ (Figure 2). Analysis under phase microscopy targeting viral occlusion bodies confirmed the pathogenic effect caused by HaNPV on field-collected dead larvae, which tended to liquefy when infected (Figure 3). 


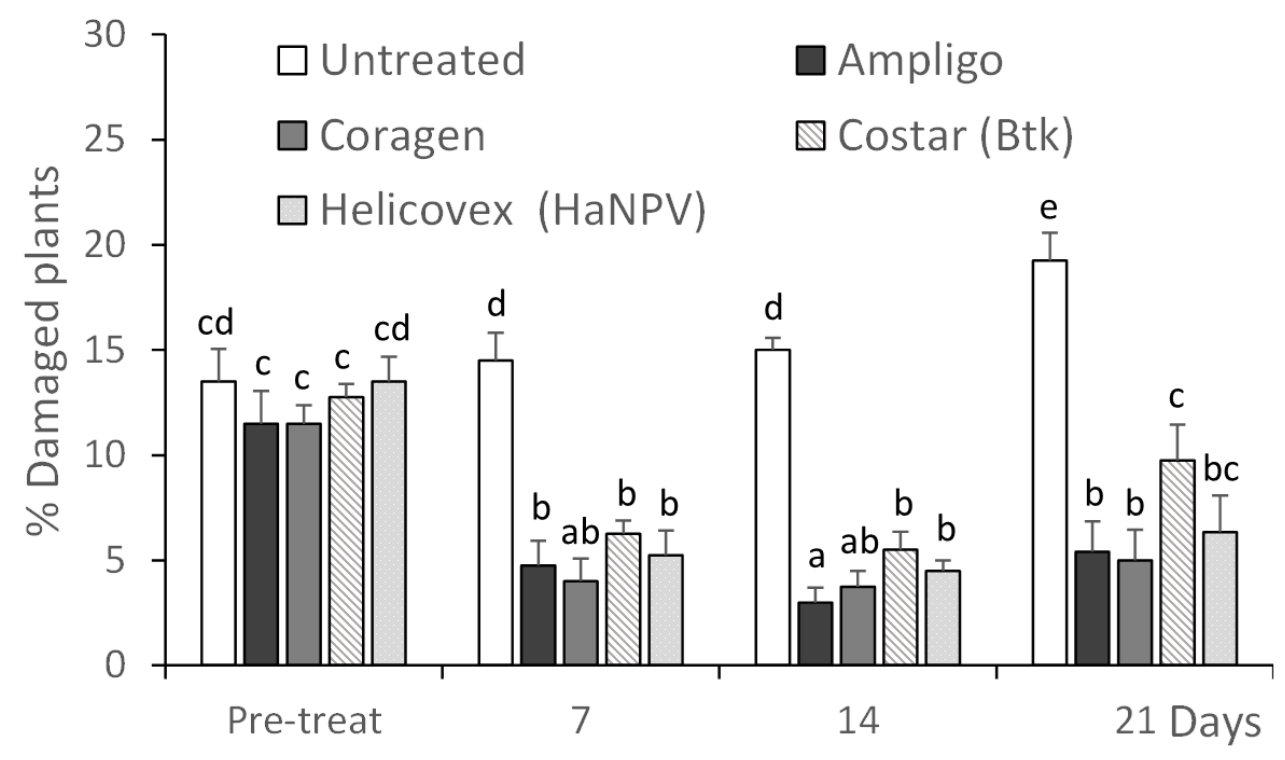

Figure 1. Percentage of damaged plants (mean \pm SD) assessed in a field with mixed infestation of $H$. armigera (dominant species) and $O$. nubilalis, before (Pre-treat) and after insecticidal applications with different products. Different letters above bars indicate significant differences among means (ANOVA Mixed Proc., $p<0.05$ ).

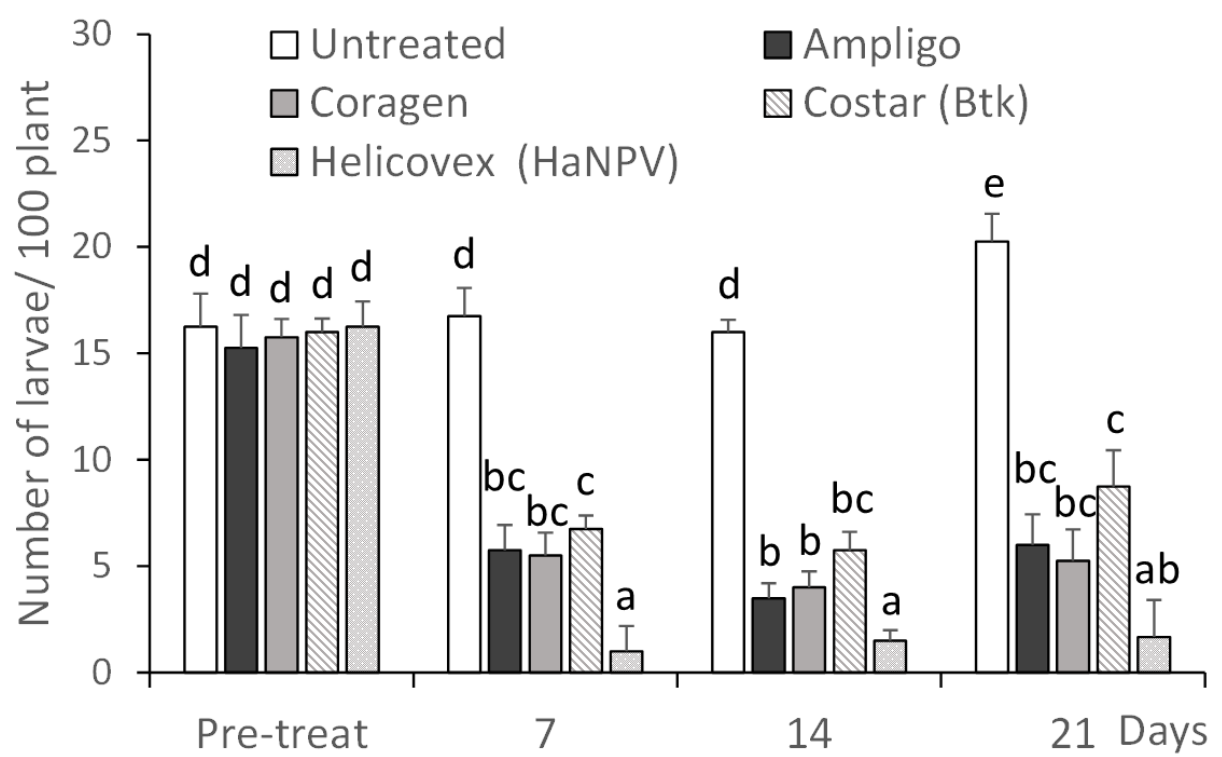

Figure 2. Density (mean $\pm \mathrm{SD}$ ) of H. armigera larvae assessed on plots before (Pre-treat) and after application of different insecticidal products. Different letters above bars indicate significant differences among means (ANOVA Mixed Proc., $p<0.05$ ). 

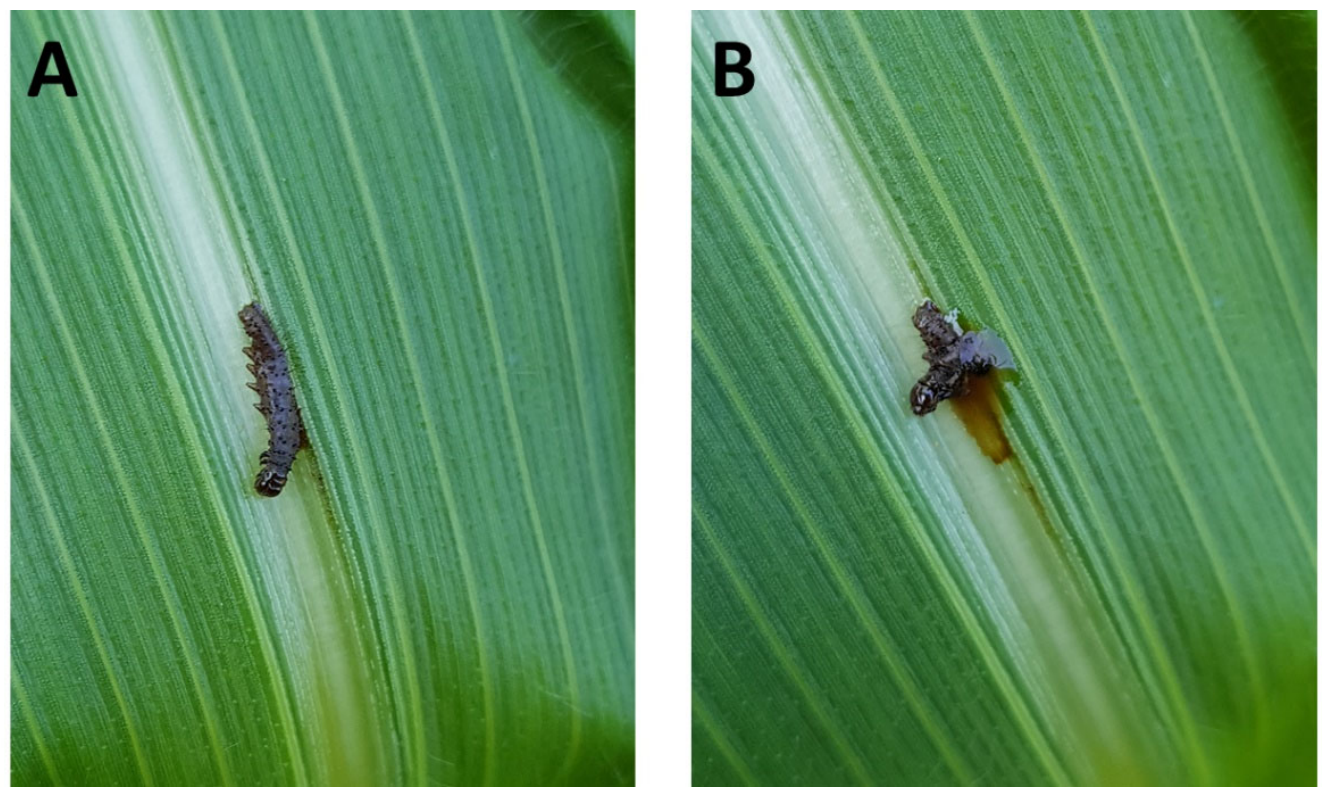

Figure 3. Representative dead Helicoverpa armigera larva infected with $\mathrm{HaNPV}$, photographed after field treatments, before (A) and after (B) being gently touched with a cotton flake.

\subsection{Experiment 2}

Infestation in the experimental fields, almost entirely represented by H. armigera, was homogeneously distributed among plots, with an average number slightly above 15 larvae per 100 plants (Figure 4). A significant drop in larval density was observed a week after applications of $B t k$ (Costar) or $\mathrm{HaNPV}$ (Helicovex), showing a significant difference between treatments $\left(F_{2,18}=11.91 ; p<0.001\right)$. Significant differences were also observed over time $\left(\mathrm{F}_{2,18}=28.31 ; p<0.001\right)$, as an increase in larval density was detected in all plots three weeks after treatments, but this overtime increase was greater in the untreated control, while a significant pest containment effect was still found in plots treated with the two bio-larvicidal products (Figure 4).

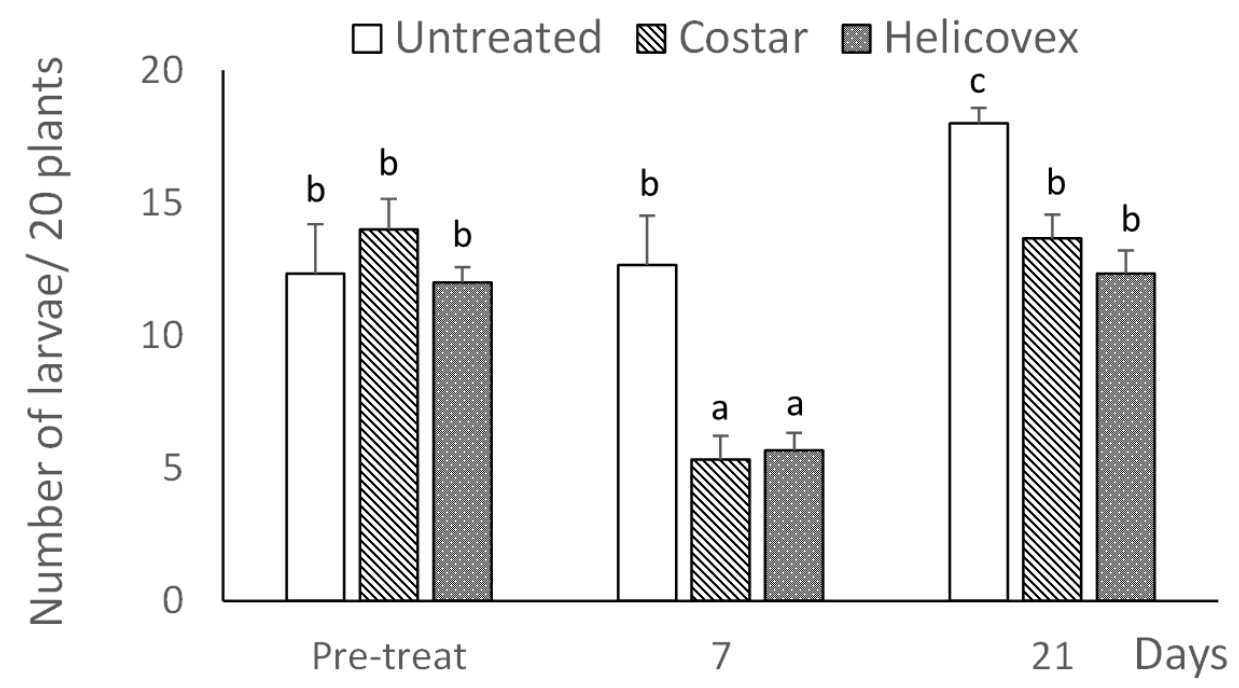

Figure 4. Density (mean $\pm \mathrm{SD}$ ) of H. armigera larvae assessed on plots before (Pre-treat) and after application of bioinsecticidal products based on Btk and HaNPV. Different letters above bars indicate significant differences among means (ANOVA Mixed Proc., $p<0.05$ ). 


\subsection{Experiment 3}

The trend of larval infestation, almost entirely represented by $\mathrm{O}$. nubilalis, on the crop during the experimental period is shown in Figure 5. Larval density was significantly affected by treatment $\left(\mathrm{F}_{3,119}=61.46, p<0.001\right)$ and time $\left(\mathrm{F}_{9,119}=55.42, p<0.001\right)$, with a significant interaction of treatment $x$ time $\left(\mathrm{F}_{27,119}=9.29, p<0.001\right)$. Application of Ampligo in mid-June caused a significant infestation decrease in both chemical and integrated management plots, with effects detectable for around one month after treatment, in comparison with the untreated control. A slight infestation containment effect (observed from outside) of Btk (BioBit) applications in July was also observed.

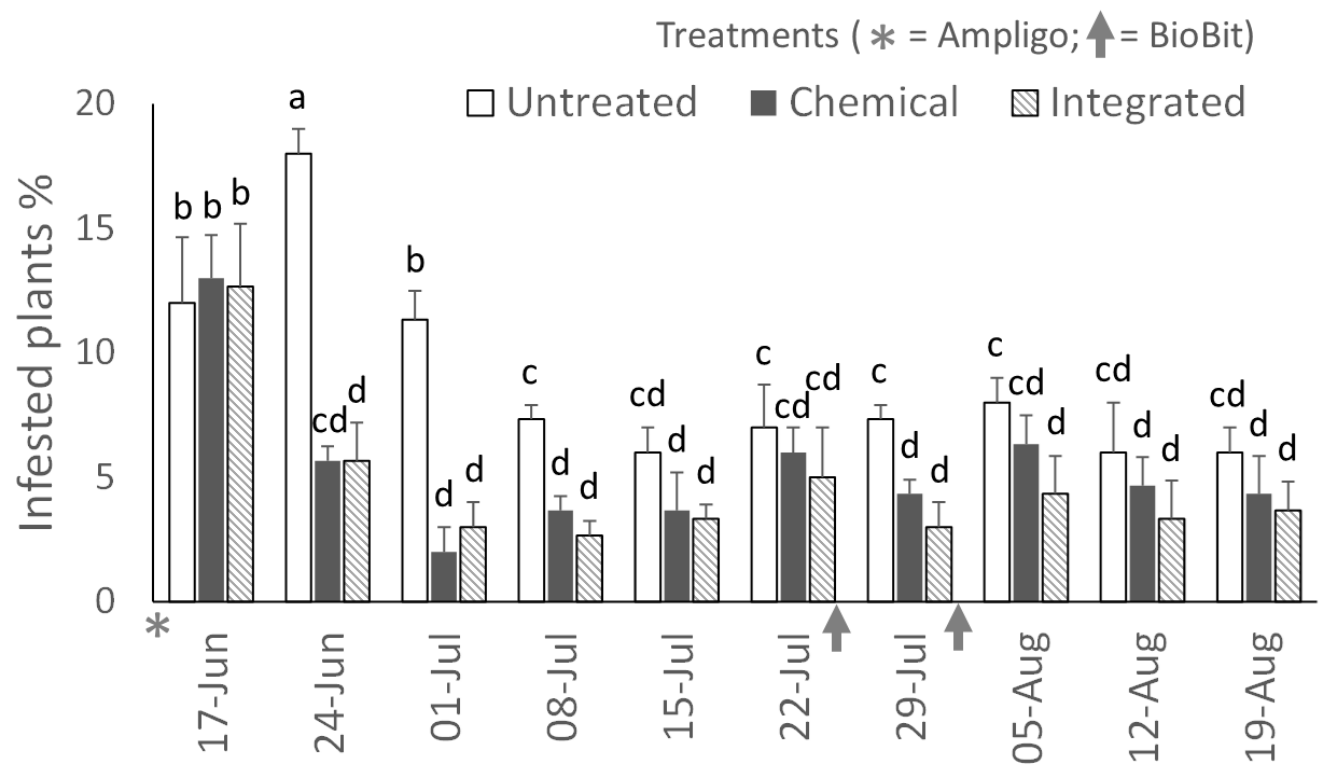

Figure 5. Dynamics of $O$. nubilalis larval density (mean \pm SD) observed from outside on treated (chemical and integrated) and untreated plants over the whole experimental period. Different letters above bars indicate significant differences among means (ANOVA Mixed Proc., $p<0.05$ ).

In-depth assessments conducted a week after the second application of Btk in the integrated plots confirmed a significant reduction in endophytic larval density $\left(\mathrm{F}_{3,23}=9.08\right.$, $p<0.001)$ and in the number of penetrating holes on affected plants $\left(\mathrm{F}_{3,23}=7.21, p=0.003\right)$, compared with untreated and chemical plots (Figures 6 and 7, respectively).

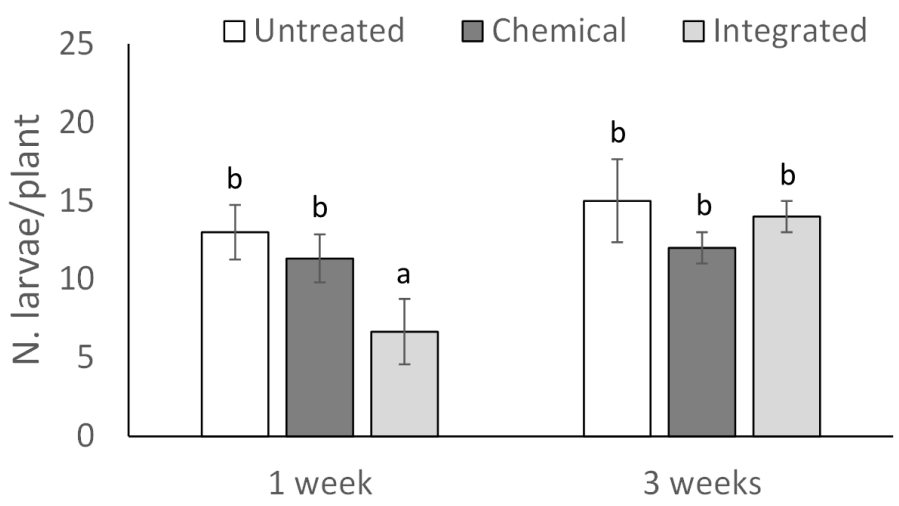

Figure 6. Density (mean $\pm \mathrm{SD}$ ) of $O$. nubilalis larvae assessed on treated (chemical and integrated) and untreated plots, one and three weeks after applications of Btk (BioBit) in the integrated plots. Different letters above bars indicate significant differences among means (ANOVA Mixed Proc., $p<0.05)$. 


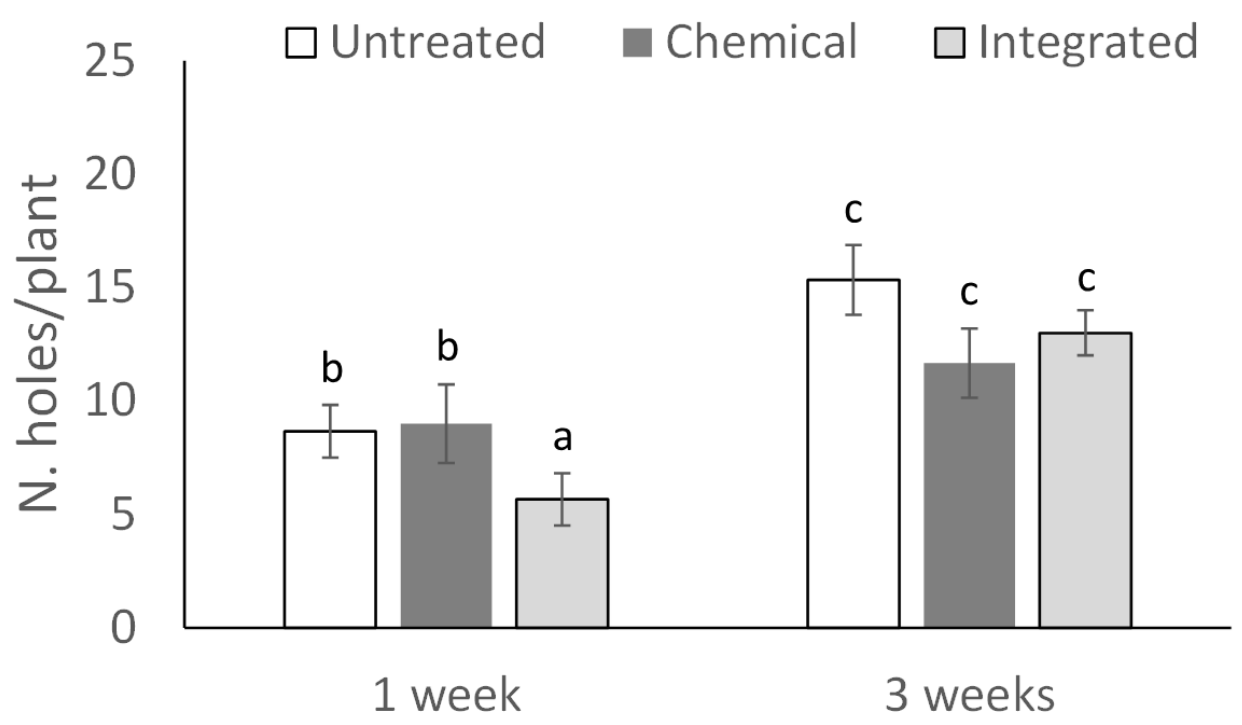

Figure 7. Density (mean $\pm \mathrm{SD}$ ) of penetrating holes of $O$. nubilalis larvae assessed on treated (chemical and integrated) and untreated plots, one and three weeks after applications of Btk (BioBit) in the integrated plots. Different letters above bars indicate significant differences among means (ANOVA Mixed Proc., $p<0.05)$.

\section{Discussion}

All tested products proved to be effective against larvae of the two major lepidopteran species infesting silage maize in the study area. As demonstrated by the preliminary trial (experiment 1), microbial control agents appeared to have comparable efficacy in respect to the reference chemical substances, commonly used by farmers. Interestingly, both Btk and $H a \mathrm{NPV}$ had significant efficacy during the stem elongation corn stage of growth, when young larvae still had significant exophytic behavior [3,19] and could easily come into contact with and ingest bacterial spores and crystals or viral occlusion bodies, both acting in the insect gut [20]. When compared with each other, the effect of the baculovirus appeared slightly more persistent than Btk, which could be related to the diversity of their mechanisms of action. In fact, the action of Btk relies on the ingestion of a sufficient amount of Cry proteins [21], which could be limited either by the larval behavior or by natural protein degradation, thus reducing their bioavailability in the agroecosystem. On the other hand, viral action can occur, albeit more slowly, even with a small initial infective inoculum [15]. However, due to its host specificity, the use of the baculovirus is limited to cases where containment needs are targeted specifically. In contrast, the use of Btk is more versatile against mixed lepidopteran pest populations. The good efficacy of $H a \mathrm{NPV}$ observed in the conditions of experiment 1 can be attributed to the prevalence of H. armigera, in respect to other lepidoptera.

Both $B t k$ and $H a N P V$ confirmed their efficacy when applied by the irrigation system in a trial conducted on a larger scale during the flowering and fruit development period, in which lepidopteran larvae infestation was almost completely represented by H. armigera (experiment 2). During this period, several larvae were frequently found on corn silk, on top of corn ears, and near the axil of the leaves, i.e., in places where they could be easily reached by bioinsecticides raining down from above, as applied by the irrigation system.

The results of this experiment provide useful information to support the application of bioinsecticides using the irrigation system [22,23]. The latter, in fact, when maize plants exceed a certain height, is one of the few, if not the only, means available to the farmer, especially in crops with a narrow planting pattern, which is very common in southern regions for this irrigated crop [24,25]. Although promising, this method should be used with care and be appropriately equipped with accessories to avoid the drift of spray droplets, to ensure appropriate calibration of volumes, and to prevent possible water source contamination, 
which represent safety issues of primary importance [16]. According to a precision farming approach, increasingly sophisticated methods, such as drip irrigation for the application of plant protection products, have been proposed against several pests, including corn lepidoptera $[26,27]$. Safety concerns that may arise could be further mitigated when priority for insecticidal application is given to selective bioinsecticides, such as entomopathogenic microbials [20]. Accordingly, the experimental hypothesis pursued in this study aimed precisely at evaluating the application of bioinsecticides whose use is allowed in organic farming, through the irrigation system. However, the use of this distribution method for agrochemicals is permitted only under specific conditions, and there are significant differences between local regulations [16]. Our study contemplated the use of the irrigation system only to apply biological insecticides, which led to the inclusion of this application option in the label of one of the Btk-based products registered in Italy (BioBit).

On the other hand, for the development of an appropriate pest management program, it is necessary to take into account the local specificities and the means actually available to the farmer, in order to optimize their use in a correct and sustainable manner. According to this principle, the results of experiment 3 provide a successful example of an integrated pest management strategy targeting corn borers, involving either a chemical product traditionally applied by a tractor-mounted spray bar during the stem elongation stage, or a Btk-based product applied by the irrigation system during flowering and fruit development, when the plants are tall and their planting pattern does not allow the tractor to enter the field. In addition to being sustainable for the farmer, this approach is consistent with recently revised legislative international frameworks fostering the sustainable use of pesticides [28].

A limitation of bioinsecticides, such as $B t k$, is the lower persistence, which emerged also in our experiment, where the efficacy of Btk applications was limited to a short period after treatment. Consequently, to ensure overtime protection of the crop against lepidoptera, applications through the irrigation system should be periodically repeated during flowering and fruit development, until harvesting. However, this would increase expenses to the farmer and should be economically evaluated for a cost-effective plant protection plan elaboration [29]. For this purpose, larval density should be correlated to the actual damage and loss of final maize product, in terms of the quality and quantity of the silage obtained [30].

Further research is needed to determine the threshold of larval density, especially in contexts where there are mixed populations, to be used as a reference to calibrate and timedistribute biocontainment interventions ensuring technical, environmental, and economic sustainability. On the other hand, the development of appropriate product formulations would allow more persistent biopesticidal action in the field, and thus more efficient crop protection.

Supplementary Materials: The following are available online at https:/ /www.mdpi.com/article/ 10.3390/agronomy12020362/s1, Figure S1: Weather data in the experimental site during the study period. Figure S2: Bioinsecticidal application system exploiting the existing irrigation equipment.

Author Contributions: Conceptualization, L.R. and A.L.; methodology, investigation, and data curation, L.R.; writing, L.R. All authors have read and agreed to the published version of the manuscript.

Funding: This research was funded by a contribution from Cooperativa Assegnatari Associati Arborea and Cooperativa Produttori Arborea in Sardinia (Italy),_Research project 2019.

Institutional Review Board Statement: Not applicable.

Informed Consent Statement: Not applicable.

Data Availability Statement: Not applicable.

Acknowledgments: The authors would like to thank Pietrangelo Giordano and Antonio Scanu from the Regional Agency for Agriculture Development LAORE (Sardinia, Italy), Mauro Panetto's family, 
Anna Marta Lazzeri and Antonella Putzulu studying at the University of Sassari, and all involved farmers, for their active cooperation in the conduction of field trials.

Conflicts of Interest: The authors declare no conflict of interest.

\section{References}

1. Grant, R.J.; Ferraretto, L.F. Silage review: Silage feeding management: Silage characteristics and dairy cow feeding behavior. J. Dairy Sci. 2018, 101, 4111-4121. [CrossRef] [PubMed]

2. Altieri, M.; Nicholls, C. Biodiversity and Pest Management in Agroecosystems, 2nd ed.; CRC Press: London, UK, 2018.

3. Beck, S.D. Developmental and seasonal biology of Ostrinia nubilalis. In Agricultural Zoology Reviews; Russell, G.E., Ed.; Intercept: Andover, UK, 1987; Volume 2, pp. 59-96.

4. Hudon, M.; LeRoux, E.J.; Harcourt, D.G. Seventy years of European corn borer (Ostrinia nubilalis) research in North America. In Agricultural Zoology Reviews; Russell, G.E., Ed.; Intercept: Andover, UK, 1989; Volume 3, pp. 53-96.

5. Sobek, E.A.; Munkvold, G.P. European corn borer (Lepidoptera: Pyralidae) larvae as vectors of Fusarium moniliforme, causing kernel rot and symptomless infection of maize kernels. J. Econ. Entomol. 1999, 92, 503-509. [CrossRef]

6. Hutchison, W.D.; Cira, T.M. Economically important maize insect pests. In Achieving Sustainable Cultivation of Maize; Watson, D., Ed.; Volume 2: Cultivation Techniques, Pest and Disease Control; Burleigh Dodds Science Publishing: Cambridge, UK, 2017; pp. 263-292.

7. Jeger, M.; Bragard, C.; Caffier, D.; Candresse, T.; Chatzivassiliou, E.; Dehnen-Schmutz, K.; Gilioli, G.; Grégoire, J.-C.; Miret, J.A.J.; Navarro, M.N.; et al. Pest risk assessment of Spodoptera frugiperda for the European Union. EFSA J. 2018, 16, 5351.

8. Musser, F.R.; Nyrop, J.P.; Shelton, A.M. Integrating biological and chemical controls in decision making: European corn borer (Lepidoptera: Crambidae) control in sweet corn as an example. J. Econ. Entomol. 2006, 99, 1538-1549. [CrossRef] [PubMed]

9. Marçon, P.C.; Young, L.J.; Steffey, K.L.; Siegfried, B.D. Baseline susceptibility of European corn borer (Lepidoptera: Crambidae) to Bacillus thuringiensis toxins. J. Econ. Entomol. 1999, 92, 279-285. [CrossRef]

10. Jurat-Fuentes, J.L.; Crickmore, N. Specificity determinants for Cry insecticidal proteins: Insights from their mode of action. J. Invertebr. Pathol. 2017, 142, 5-10. [CrossRef]

11. Rice, M.E.; Plicher, C.D. Potential benefits and limitations of transgenic Bt corn for management of the European corn borer (Lepidoptera: Crambidae). Am. Entomol. 1998, 44, 75-78. [CrossRef]

12. Meissle, M.; Romeis, J.; Bigler, F. Bt maize and integrated pest management-A European perspective. Pest Manag. Sci. 2011, 67, 1049-1058. [CrossRef]

13. Moscardi, F. Assessment of the application of baculoviruses for control of Lepidoptera. Annu. Rev. Entomol. 1999, 44, 257-289. [CrossRef]

14. Clem, R.J.; Passarelli, A.L. Baculoviruses: Sophisticated pathogens of insects. PLoS Pathog. 2013, 9, e1003729. [CrossRef]

15. Williams, T.; Virto, C.; Murillo, R.; Caballero, P. Covert infection of insects by baculoviruses. Front. Microbiol. 2017, 8, 1337. [CrossRef] [PubMed]

16. Bayabil, H.K.; Migliaccio, K.W.; Crane, J.H.; Olczyk, T.; Wang, Q. Regulations and Guidelines for Chemigation. EDIS 2020, 2020, 5. [CrossRef]

17. European and Mediterranean Plant Protection Organization (EPPO). Guideline for the efficacy evaluation of insecticides. Ostrinia nubilalis. Bull OEPP 1995, 25, 415-482.

18. R Development Core Team. R: A language and environment for statistical computing. Vienna: R Foundation for Statistical Computing. 2016. Available online: http:/ / www.R-project.org (accessed on 29 December 2021).

19. Johnson, M.L.; Zalucki, M.P. Foraging behaviour of Helicoverpa armigera first instar larvae on crop plants of different developmental stages. J. Appl. Entomol. 2005, 129, 239-245. [CrossRef]

20. Ruiu, L. Microbial Biopesticides in Agroecosystems. Agronomy 2018, 8, 235. [CrossRef]

21. Ruiu, L. Insect Pathogenic Bacteria in Integrated Pest Management. Insects 2015, 6, 352-367. [CrossRef]

22. Walgenbach, J.F.; Bilbo, T.R.; Tussey, D.A.; Ogburn, E.C. Comparison of chemigation versus foliar insecticide use: Management of lepidopteran larvae and stink bugs in North Carolina field tomatoes with environmental and farmworker benefits. Pest Manag. Sci. 2021, 77, 758-765. [CrossRef]

23. Nolting, S.P.; Poston, F.L. Application of Bacillus thuringiensis through center-pivot irrigation systems for control of the southwestern corn borer and European corn borer (Lepidoptera: Pyralidae). J. Econ. Entomol. 1982, 75, 1069-1073. [CrossRef]

24. Li, X.; Jiang, H.; Wu, J.; Zheng, F.; Xu, K.; Lin, Y.; Zhang, Z.; Xu, H. Drip application of chlorantraniliprole effectively controls invasive Spodoptera frugiperda (Lepidoptera: Noctuidae) and its distribution in maize in China. Crop Prot. 2021, 143, 105474. [CrossRef]

25. Keller, J.; Bliesner, R.D. Sprinkle and Trickle Irrigation; Blackburn Press, T.H.E.: New York, NY, USA, 2000; 652p.

26. Wriedt, G.; Van der Velde, M.; Aloe, A.; Bouraoui, F. Estimating irrigation water requirements in Europe. J. Hydrol. 2009, 373, 527-544. [CrossRef]

27. Lamm, F.R.; Ayars, J.E.; Nakayama, F.S. Microirrigation for Crop Production: Design, Operation, and Management; Elsevier: Oxford, UK, 2006.

28. Villaverde, J.J.; Sevilla-Morán, B.; Sandín-España, P.; López-Goti, C.; Alonso-Prados, J.L. Biopesticides in the framework of the European Pesticide Regulation (EC) No. 1107/2009. Pest Manag. Sci. 2014, 70, 2-5. [CrossRef] [PubMed] 
29. Matyjaszczyk, E. “Biorationals" in integrated pest management strategies. J. Plant Dis. Prot. 2018, 125, 523-527. [CrossRef]

30. Masoero, F.; Gallo, A.; Zanfi, C.; Giuberti, G.; Spanghero, M. Chemical composition and rumen degradability of three corn hybrids treated with insecticides against the European corn borer (Ostrinia nubilalis). Anim. Feed Sci. Technol. 2010, 155, 25-32. [CrossRef] 